\title{
Retraction Note: Endothelial progenitor cell-derived exosomes, loaded with miR-126, promoted deep vein thrombosis resolution and recanalization
}

Jiacheng Sun ${ }^{4 \dagger}$, Zhiwei Zhang ${ }^{3+}$, Teng Ma ${ }^{4 \dagger}$, Ziying Yang ${ }^{4 \dagger}$, Jinlong Zhang ${ }^{4}$, Xuan Liư ${ }^{4}$ Da Lu ${ }^{4}$, Zhenya Shen ${ }^{4 *}$, Junjie Yang ${ }^{2,4^{*}}$ and Qingyou Meng ${ }^{1,4^{*}}$

Retraction Note: Stem Cell Res Ther (2018) 9:223

https://doi.org/10.1186/s13287-018-0952-8

The authors have retracted this article [1] because there is erroneous data in Figure 1C. Flow cytometry results of EPC cell markers CD31 and CD45 could not be replicated. Due to incorrect cell markers, the cells cultured may not have been pure EPCs. Therefore the scientific content of the article is no longer reliable. All authors agree to this retraction.

\footnotetext{
Author details

${ }^{1}$ Department of Vascular Surgery, The Second Affiliated Hospital of Soochow University, Suzhou 215000, China. ${ }^{2}$ Department of Biomedical Engineering, University of Alabama at Birmingham, Birmingham, Alabama 35294, USA. ${ }^{3}$ Department of Cardiothoracic Surgery, The Second Affiliated Hospital of Soochow University, Suzhou 215004, China. ${ }^{4}$ Department of Cardiovascular Surgery of the First Affiliated Hospital and Institute for Cardiovascular Science, Soochow University, Suzhou 215000, China.
}

Received: 10 May 2019 Revised: 14 May 2019

Accepted: 14 May 2019 Published online: 11 June 2019

\section{Reference}

1. Sun J, Zhang Z, Ma T, Yang Z, Zhang J, Liu X, Lu D, Shen Z, Yang J, Meng Q.

Endothelial progenitor cell-derived exosomes, loaded with miR-126, promoted deep vein thrombosis resolution and recanalization. Stem Cell Res Ther. 2018;9(1):223. https://doi.org/10.1186/s13287-018-0952-8.

\footnotetext{
*Correspondence: zhenyashen@sina.cn; junjieyang2009@gmail.com; mengqy@163.com

${ }^{\dagger}$ Jiacheng Sun, Zhiwei Zhang, Teng Ma and Ziying Yang contributed equally to this work.

${ }^{4}$ Department of Cardiovascular Surgery of the First Affiliated Hospital and Institute for Cardiovascular Science, Soochow University, Suzhou 215000, China

${ }^{2}$ Department of Biomedical Engineering, University of Alabama at Birmingham, Birmingham, Alabama 35294, USA

'Department of Vascular Surgery, The Second Affiliated Hospital of Soochow University, Suzhou 215000, China

Full list of author information is available at the end of the article
}

(c) The Author(s). 2019 Open Access This article is distributed under the terms of the Creative Commons Attribution 4.0 International License (http://creativecommons.org/licenses/by/4.0/), which permits unrestricted use, distribution, and reproduction in any medium, provided you give appropriate credit to the original author(s) and the source, provide a link to the Creative Commons license, and indicate if changes were made. The Creative Commons Public Domain Dedication waiver (http://creativecommons.org/publicdomain/zero/1.0/) applies to the data made available in this article, unless otherwise stated. 